\title{
LECTURERS' POLITENESS STRATEGIES AND STUDENTS' COMPLIANCE IN ENGLISH FOR FOREIGN LANGUAGE (EFL) CLASS
}

\author{
Fitriyah, Nurmala Dewi, Octa Pratama Putra, Meiva Eka Sri Sulistyawati \\ Universitas Bina Sarana Informatika (UBSI), Jakarta, Indonesia \\ E-mail: fimasy74@gmail.com
}

Received: 22 April 2020

Accepted: 22 May 2020

\begin{abstract}
The aim of this study is to find out the politeness strategies used by the teachers and students, and how the politeness affects to the student's compliance. The focus is on directive and expressive speech acts in English for Foreign Language (EFL) Class. The subjects of this study were three lecturers and the students of three English classes. In data collecting procedure, the researcher used observation techniques. The observation was used to record the audio and video of teaching and learning process from the beginning until the end of the class. The audio-record of teaching and learning process will be transcribed into convention transcript, and then the transcript will be selected and classified into ten maxims in doing politeness strategies. The analytical part adopts the viewpoints of Leech's (2014) "The Components Maxims of the General Strategy of Politeness". In the data analysis, it is found that 1) the teachers used ten maxims in their communication to the students. They are tact maxim, generosity maxim, approbation maxim agreement maxim, Obligation (of $S$ to 0 ) maxim, sympathy maxim, modest maxim, Obligation (of $\mathrm{O}$ to $\mathrm{S}$ ) maxim, Opinion reticence maxim, and feeling reticence maxim. 2) The lecturers dominantly used tact maxim in their directive speech acts to the students. The last part of this paper aims at summarizing the implications that this paper, its theoretical summary, and its research, have for teaching English as a Foreign Language (EFL) class.
\end{abstract}

Keywords: politeness strategies, politeness maxims, English for Foreign Language (EFL), student's compliance, teaching and learning process

\section{Introduction}

To learn a language communicatively, one must know the rules governing the language beyond its structural properties. The rules help the learner to take into consideration the person whom he is talking with, paying attention to the situation, acting in the way required, and choosing the best way of conveying the message, so as not to ruin the self-image of others. (Fitriyah, Emzir, \& Ridwan, 2019).

Politeness becomes one of important issues in Indonesian education recently. Most students tend to speak impolitely, and they prefer to use slang or informal language at school. Therefore, a teacher has a responsibility to teach their students how to speak politely and admonish them if they speak impolitely at school especially during classroom interaction. Moreover, a teacher also needs to speak politely in front of the students in order to influence them to speak politely too. In addition, the implementation of politeness 
Lecturers' Politeness Strategies and Students' Compliance in English for Foreign Language (EFL) Class, Fitriyah, Nurmala Dewi, Octa Pratama Putra, Meiva Eka Sri Sulistyawati

strategy is relevant with curriculum 2013 which emphasize on good character because politeness strategy deals with someone's ability to show his good character. Therefore, the teacher is obliged to implement it in the language learning activities along with language usage.

One of the purposes of learning English as a foreign language (EFL) is to be able to communicate. Students must have communicative competence that does not only consist of linguistic competencies, but also socio-cultural competencies, interactions, formulas and strategies (Celce-murcia, 2007). Kasper in Senowarsito (2013) says that sociocultural, interactional, and strategic competencies refer to the speaker's pragmatic knowledge. Pragmatic perspectives can be specifically defined as knowledge of communicative actions and how to apply them, and the ability to use language appropriately in context. Classroom is a sociolinguistic environment and discourse community where we speak using various language functions to build a communication system, and the interaction of teachers and students is believed to contribute to the development of student language (Consolo, 2006).

Classroom is also a place of the interaction process which happens between a teacher and students. It must be effective and polite. If in the classroom interaction runs well, the knowledge that will be delivered by the teacher will be received by students well. Teacher professional role endows them with right to evaluate students' behaviors, constrain their freedom of actions, control resources and give critical feedback, which unavoidably poses threat to students' positive and negative face (Jiang, 2010). In addition, teacher is as the model in the class and the students will imitate the way the teacher teaches them. Therefore, in creating good interaction in the classroom, teachers and students should make the good interaction.

According to Rod Ellis (1997), teachers' language can be termed as teachers' talk, teachers' speech, or teachers' utterance, which is all about the language use in class. English classrooms are places where different cultures interact. Students learn about new cultures. When students enter a language class, they bring along their own cultural background and experience, which may be different from their teacher and classmates. Often students do not realize the importance of culture in language learning. A teacher (educator) not only has the responsibility to introduce students to foreign cultures and languages, but also has an obligation to realize the cultural impact on students' daily lives.

In EFL classroom, English is not only the target language for students to learn, but also a medium for teachers to teach English. EFL teachers are the models for the students to imitate while their language is the most important source for students to gain the knowledge of the language. Krashen in Console (Consolo, 2006) concludes that the purpose of teaching language in a certain sense is to provide an example of the optimal language for the learner to gain the best profit and input for the language learning process. Teachers' language is a language applied in a special language situation, while politeness is regarded as a most favorable strategy in interpersonal relationship.

Language politeness is often conveyed to language learners implicitly, basically as things they should or should not say and do when interacting in English. Generally, presents politeness as done and should not be done in accordance with the structure of the language being taught. Appropriate polite interaction is reflected prominently in speech acts so that the teacher can help students understand polite communication in accordance with the culture of the target language. If the structure of the communicative language is related to greetings, the teacher can introduce the social context and ask students to explore various forms of greeting in the context of the target language and their own culture. By exploring 
greetings and communicative variables that are socially appropriate in their own cultural context, the teacher can then help students understand appropriate communication in the target language. For example, Hey, where are going? maybe linguistically correct, but not proper polite speech in English. Understanding the discourse of manners and how thorough politeness affects all aspects of daily social interaction among students themselves can lead to a deeper understanding and awareness of politeness in the target language.

Normally in EFL classrooms, teachers are unavoidable to correct something that a student has said, done, or written. When this correction involves a negative evaluation of a student's trying, a face-threatening act happens. When the student is asked for further explanations, teachers' instructions might be a threat to him/ her because teachers are threatening the student's freedom of action, thus further threaten his/her negative face. Teachers offering for help might also regarded as an FTA because it threatens students' negative face when teachers suggest that students may owe a debt to teachers and threaten students' positive face when teachers imply that students need help (Peng, Xie, \& Cai, 2014).

Although many language politeness studies have been carried out, this small study tries to explore the language politeness in the classroom. Other research that investigates politeness in an academic context, including Sabee and Wilson (2005). They research the main goals, attribution, and facework of students in conversations with their teachers about disappointing values, as well as various FTAs and politeness strategies that they do (Sabee \& Wilson, 2005).

In this paper, we focused on the phenomenon of teacher's speech acts to students' compliance in the context of politeness. It is believed that teacher's politeness has an indirect effect on student compliance intention to enhance desired outcomes in the classroom. As it is found in some researches that speaker's politeness relates to the hearer's compliance. According to Zhang (2009), teachers' high politeness was found to be more likely to elicit positive emotions such as happiness and lead to compliance and vice versa to the low politeness that evoked negative emotions and caused resistance.

However, based on researcher's observation of lecturers' utterances and students' compliances in EFL at Islamic college Jakarta, it is not as expected. Some of lecturers use impolite utterances to their students and the impolite utterances affect to students' compliances. Being polite in classroom interaction is very important to create effective teaching learning process. It can be shown by using some principles of politeness. In this research, the effects of lecturers' politeness on students' compliance were the focus of the study. Politeness has been proved as one thing that affect to students' compliance to college students.

In conducting this research, we are interested to analyze the use of politeness strategies used by the lecturer and the students in the teaching process in EFL Class. Therefore, we have two research questions.

The research questions are formulated as:

1) What are politeness strategies used by the lecturers to the students in EFL Class at an Islamic college?

2) What are the most frequent politeness strategies used by the lecturers to the students in EFL Class at an Islamic College?

In this study, we used Leech's theory (2014) "The Components Maxims of the General Strategy of Politeness", which introduces ten maxims. They are tact maxim, generosity maxim, approbation maxim agreement maxim, Obligation (of $\mathrm{S}$ to $\mathrm{O}$ ) maxim, sympathy maxim, modest maxim, Obligation (of $O$ to $S$ ) maxim, Opinion reticence maxim, and feeling 
Lecturers' Politeness Strategies and Students' Compliance in English for Foreign Language (EFL) Class, Fitriyah, Nurmala Dewi, Octa Pratama Putra, Meiva Eka Sri Sulistyawati

reticence maxim. To make the study more specific, we focused just on directives and expressive speech acts.

\section{Literature Review}

Politeness behaviour is a polished behaviour relying on social conventions, which are socially institutionalized and evaluated. Its main motivations are keeping a cooperative social interaction and avoiding unnecessary conflicts. In other words, politeness works to maintain social status quo and shun devaluation by others. The behaviour or the speech acts perceived as 'polite' may vary from speaker to speaker, and from community to community, depending on the social contexts involved in the situation. Politeness is inherent to the communicative acts but is connected to an interactional relationship which is transmediated by a social standard determined by cultural norms. Accordingly, it is important for the members of the society to acknowledge social consensus among the constituent members of the society and to be perceived to be appropriate by the members of the society (Watts, 2003).

Politeness has several characteristics (Song, 2012). First, according to Goffman, a person is obliged to protect both his own 'face' and the 'faces' of others in social interactions. Goffman defines the concept of face as the positive social value a person claims for himself by the line others assume, he has taken during a particular contact. According to Goffman, 'Face is an image of self-delineated in terms of approved social attribute ... The person's face clearly is something not lodged in or on his body but rather something that is diffusedly located in the flow of events in the encounter and becomes manifest only when these events are read and interpreted for the appraisals expressed in them' (Goffman, 1967: 577).

Based on Goffman's notion of social self, Brown and Levinson (1987: 61) define face as 'the public self-image that every member wants to claim for himself/herself'. Both Goffman's and Brown and Levinson's views argue that face is something to be established, maintained, improved, misplaced, and rebuilt in social interactions. In other words, face is a kind of illustration or reputation that people want for themselves in terms of others' view of them, which is a typical definition of face in American or European culture (Song, 2012).

On the other hand, the concept of face in East Asia is somewhat different from that in American and European cultures because it contains an element that is group-identity oriented (Song, 2012). For instance, in her study of Thai face idioms, Ukosakul in Lakoff and Ide (2005: 119) defines face as a term which includes 'personality, emotions, honour, selfesteem, prestige, reputation and pride'. Wakimae's definition of face in Japan is similar: 'one's sense of self and relation to others' (recited from Ide, 2005). Regardless of nation or culture, however, the concept of face as a social self in the given culture has provided the basis for most politeness theories.

Previous studies on politeness can be categorized into three groups: the conversational-maxim perspective, the face-saving view, and the social norm theory. The first two groups of politeness theories consider politeness phenomena as universal rationality - universal rules and standards - within linguistic pragmatics, which started from a Grecian speech-act theoretic perspective. According to these perspectives, the speaker's intention receives first priority, which is more or less the same regardless of culture (Song, 2012). The second generation of theoretical studies concerning politeness adopted the facesaving perspective, which was initially proposed by Brown and Levinson (1987). The facesaving view has had a significant impact on linguistics literature by theorizing and analysing 
politeness phenomena. According to this view, all members of the society try to save face to maintain their self-esteem, which is the main incentive to employ polite speech acts in communication. The most recent approach concerning politeness is the social norm perspective (Eelen, 2001, Watts, 2003, Lakoff \& Ide, 2005). This approach accepts the general argument of the face-saving view, but adds the effects of various socio-cultural factors, such as cultural norms, social approval and consensus on speech acts with respect to politeness in studying linguistic politeness. Thus, this school of thought is more sensitive to cultural differences and its effects of politeness acts.

\section{Leech's Politeness Theory}

Leech (2014) has proposed a way of explaining how politeness operates in communication to other, which is called Politeness Principles. Politeness principles are a series of maxim used in analyzing politeness. They are: tact maxim, generosity maxim, approbation maxim, modesty maxim, obligation $\mathrm{S}$ to $\mathrm{O}$ maxim, obligation $\mathrm{O}$ to $\mathrm{S}$, agreement maxim, opinion-reticence maxim, and sympathy maxim, and feeling-reticence maxim.

\section{(1) Generosity Maxim (Give a high value to O's wants)}

The intent of this maxim of generosity is making the advantages of you as small as possible; make oneself loss as big as possible. In maxims charity or generosity maxim, the participants are expected substitutions being respectful of others. Respect for others will happen if people can reduce profits for himself and maximize profits for others. For example, offers, invitations, and promises are (in default terms) "generous" and, in English, can be direct or even impositioning. In example (1) - (3), insistent directive features are followed:

(1) Let me wash your clothes too. I just have the same thing to be washed, really

(2) No, Mom. I will wash them later today.

(3) No, you don't! I'll pay for this. I insist.

The Generosity Maxim can also be seen at work in positive, compliant replies to requests, which can show intensified equivalents of yes, as in Yes, of course; Certainly; Sure; etc. But refusals of requests are "ungenerous" and often must be very indirect or even unspoken.

\section{(2) Tact Maxim (Give a low value to $S^{\prime} s$ wants)}

Tact maxim is meant that the speaker tries to be tactful in communication by minimizing the expression of beliefs which imply cost to other and maximizing the expressions of beliefs which imply benefit to others. For example, requests are often indirect, tentative, giving an opportunity to refuse, and softening, or mitigating, $S$ 's imposition on $H$. This is such a familiar aspect of politeness that it scarcely needs exemplification here. But here is one rather extreme example of a polite request and a polite reply (illustrating the Generosity Maxim):

(4) A: Could I help myself to a tiny sip of sherry?

B: Of course you can! Have as much as you like.

(5) Could I interrupt you for a second to help me?

(6) Please take your dinner, I have prepared for you.

In this tact maxim, the speakers try to minimize cost to others and maximize benefit to others. 
Lecturers' Politeness Strategies and Students' Compliance in English for Foreign Language (EFL) Class, Fitriyah, Nurmala Dewi, Octa Pratama Putra, Meiva Eka Sri Sulistyawati

(3) Approbation Maxim (Give a high value to $O$ 's qualities)

This approbation maxim is expressed by expressive sentence by minimizing the expression of beliefs which express dispraise of other; maximize the expression of beliefs which express approval of other. It is preferred to praise others and if this is impossible, to side step the issue, to give some sort of minimal response (possibly using euphemisms), or to remain silent. For example, we like to pay (and be paid) compliments, if it seems appropriate to do so. (Insincere or excessive compliments count as flattery and receive a more mixed reception; here the CP clashes with the PP.) Run-of-the-mill compliments like Your garden looks so lovely and What a pretty dress! are familiar occurrences. In some activity types complimentary language is a virtual necessity, as when guests praise a host(ess)'s meal, or an academic introduces the lecture of a visiting senior professor:

(7) They are so delicious! Your cuisine is as good as that of a chef at any big restaurant!'

(8) It's a great honour for us to have invited Professor $X$ who has made great contribution to the field to give us a lecture.'

(4) Modesty Maxim (Give a low value to $S$ 's qualities)

Self-deprecation (if sincere, even if exaggerated) is often felt to be polite. In the maxim of simplicity or modesty maxim, participants are expected humble by reducing the praise to him. In the Indonesian language community, simplicity and humility are widely used as parameter assessment of one's modesty. If the maxim of generosity or appreciation centered on others, modesty maxim is self-centered.

This maxim requires each participant to maximize dispraise of self and minimize praise of self. For example:

(9) "How stupid I am!"

(10) "I don't think I will do it well. I am still learning."

In this maxim, we try to minimize the expression of praise of self and maximize the expression of dispraise of self.

(5) Obligation of $\mathbf{S}$ to $O$ Maxim (Give a high value to $S^{\prime} s$ obligation to 0 )

Apologies for some offense by $\mathrm{S}$ to $\mathrm{H}$ are examples of polite speech acts giving high prominence to $S$ 's fault and obligation to $O$. Here are some typical brief examples, with the overtly apologetic forms underlined:

(11) I'm (terribly) sorry. I Please excuse me. I I'm afraid I'll have to leave early. A similar case is the expression of gratitude for some favor $\mathrm{H}$ has done to $\mathrm{S}$ :

(12) Thanks. I Thank you very much. I Thank you very much indeed.

(6) Obligation of $O$ to $S$ Maxim (Give a low value to O's obligation to S)

On the other hand, responses to apologies often minimize the fault: It's OK. Don't worry. It was nothing. Similarly, responses to thanks often minimize the debt: That's all right. You're welcome. No problem. Glad to be of help. It was a pleasure. In Chinese:
(13) A : Sorry
B: It's all right.

(7) Agreement Maxim (Give a high value to $O$ 's opinions)

In this maxim is emphasized that the participants can develop agreement on the speech acts. If there is a match between themselves or speaker and hearer in the speech acts, each one of them will be said to be polite.

For example: 
(14) "Let's have dinner together, ok?"

(15) "Good idea, I will wait for you at Sunda restaurant."

In this conversation, we can infer that the speakers are able to build their agreement so that they will be polite each other.

(8) Opinion - Reticence Maxim (Give a low value to S's opinions)

As shown in the last example, people frequently soften the force of their own opinions, by using propositional hedges such as I think, I guess, I don't suppose, It might be that. . . . In other cases, $S$ consults $H^{\prime}$ s opinion, deferring to $H^{\prime}$ 's supposed greater understanding, wisdom, or experience. In contrast, there is a low tolerance of opinionated behavior, where people express themselves forcefully, as if their opinions matter more than others'.

(9) Sympathy Maxim (Give a high value on O's feelings)

In this maxim, the speakers try to minimize antipathy between self and others and try to maximize sympathy between self and others. A constraint of Sympathy (or emotive concern) is needed to explain why we give a high value to other people's feelings in such speech acts as congratulations and condolences. It is polite to show others that you share their feelings, feeling sad when they have suffered misfortune, and feeling joyful when they have cause for rejoicing. Congratulations, good wishes, and condolences are all intrinsically courteous speech acts and need no mitigation: Congratulations! Well done. Have a good time! Enjoy your meal. Or on a sadder note: I was so sorry to hear about your father. . . Like condolences are inquiries about people's health, showing sympathy and concern: How's your mother? I hope she's feeling better. . . . Since these are all courteous speech acts, they can be made more pragma linguistically polite by intensification. That is, it is easy to make them more extreme, by heightening the degree of gradable expressions they contain (intensifying expressions are underlined):

(16) Warmest congratulations!

(17) "I was sorry to hear about you father."

(18) "I take a pity on hearing you didn't pass the exam."

(10) Feeling - Reticence Maxim (Give a low value to S's feelings)

The corresponding negative-politeness constraint places a low value on one's own feelings. For example, B\&L (1978: 240) say “it appears that in English one shouldn't admit that one is feeling too bad," and quote the following:

(1) A: Hi, how are you?

B: Oh, fine. Actually though. ...

The first response to questions like How are you? is likely to suppress any bad news, even though speaker B may be tempted to share his or her troubles.

\section{Students' Compliance}

Individuals are frequently rewarded for behaving in accordance with the opinions, advice, and directives of authority figures. Compliance refers to a kind of responseacquiescence--to a kind of communication-a request (Cialdini \& Goldstein, 2004). The request may be explicit, as in the direct solicitation of funds in a door-to-door campaign for charitable donations, or it may be implicit, as in a political advertisement that touts the qualities of a candidate without directly asking for a vote. But in all cases, the target 
Lecturers' Politeness Strategies and Students' Compliance in English for Foreign Language (EFL) Class, Fitriyah, Nurmala Dewi, Octa Pratama Putra, Meiva Eka Sri Sulistyawati

recognizes that he or she is being urged to respond in a desired way. Although students may respond to teachers' compliance-gaining requests by resisting, generally teachers expect that their requests result in student compliance because of their role-related authority and because resistance tends to be counter-productive or disruptive in classroom settings. Despite teachers' best efforts to generate compliance, sometimes their requests incur resistance from students. Thus, it is important to examine how to enhance compliance and reduce resistance in teacher requests.

Many factors (e.g., linguistic, contextual, and relational) may influence students' responses to teacher requests, such as what the request is, how the request is made, and whether the teacher is perceived by their students as credible. With these questions in mind, we examined how request politeness and legitimacy, teacher-student relationship distance, and teacher credibility affect students' intention. Students could comply with or resist teachers' requests. Student compliance refers to students' going along with teachers' compliance-gaining attempts, whereas student resistance refers to students' opposition to teachers' requests. Given the asymmetrical teacher-student relationships, students are more likely to comply or partially comply with teachers' requests even if they feel resistant. (Zhang, 2009). Teachers' authority in the classroom has boundaries, so their requests can be perceived as legitimate or illegitimate, which is largely norm based. A legitimate request is one that is perceived as the same as or better than students' expectations, whereas an illegitimate request is one that is perceived as worse than students' expectations. We found that students' perceptions of teacher request legitimacy help reduce student resistance intention.

\section{Research Method}

The method of this research is qualitative with content analysis techniques. Krippendrof (2003: 87) states that this analysis must be carried out and justified in relation to the data context. The data is utterances spoken by lecturers and students during teaching and learning interactions. In addition, this study also analyzed conversations conducted by students. Eggins and Slade (1997) stated that conversation analysis is a branch of ethnomologists who focus on a conversation because conversation analysis is specifically in accordance with the data examined in ethnomology, namely what people say and do. Littlejohn and Foss (2008) stated that conversation is a sequence of interactions, namely the beginning of the conversation and the end of the conversation, the turn of speech and the purpose of the conversation. In this study a qualitative approach was used with the following reasons: 1) The data are English-politeness that occurs in teaching and learning interactions in English classes, 2) In this study, the data obtained naturally, that is when lecturers and students interact during the teaching and learning process in English classes.

The respondents in this study are the lecturers and the students in EFL classroom at Islamic College Jakarta. The English for foreign language Class is divided into three classes. They are class A (Speaking class with 22 students), class B (Reading and Vocabulary class with 23 students), and class C (Grammar class with 25 students). In this EFL classroom, the teaching and learning process takes place for 90 minutes.

In this study the researchers use: 1) Observation. The researcher noted things that happened outline during the process of learning English in the class. 2) Recording. When lecturers and students interact in learning English, the researcher recorded using video and tape recorders. After recording the object under study, the next step is to listen to the recording. This technique is by listening to the utterances of the politeness of the language 
used in teaching and learning interactions. The recordings are played many times, every observation and series of utterances are examined. What topics are discussed, where the conversation takes place, etc., and 3) Interview. Interviews were conducted to gain a deeper understanding of language politeness conducted by lecturers and students during the process of learning English. Interviews were conducted to verify the results of the study that had been carried out through the context of the conversation that had been previously transcribed.

Data analysis in this study was carried out by content analysis techniques with deductive procedures. This means that the data obtained are analyzed, then grouped into previously defined categories. Aspects of the interpretation of the text following the research questions are included in the categories. these categories can be revised and verified together with the course of the analysis process (Krippendorff, 2003). The procedures are: a) Listen carefully and repeat the recording conversations between lecturers and students during speaking lecture, reading, structure and then transcribed, b) Identify and classify the phenomena found based on the focus of the research, c) Encoding data, d) Compare the phenomena found in the identified segments with other segments contained in conversations in English classes, e) Interpret the findings, f) Interview with the participants, g) Triangulate colleagues who are linguistically based, and colleagues who are non-linguistic.

\section{Results and Discussion}

According to Leech (2014), there are ten maxims used in politeness principle in analyzing politeness. Politeness involves minimizing the cost and maximizing the benefit to speaker. Theoretically, the politeness principle consists of ten maxims namely tact maxim, generosity maxim, approbation maxim, modesty maxim, agreement maxim and sympathy maxim. The lecturers used Politeness principles in their speech. From the observation conducted in English class at Islamic College Jakarta, it was found that the teachers used ten types of politeness strategies in their communication. The following are the frequency of the ten types of politeness strategies used by the lecturers according to the theory of politeness principles by Leech (2014).

Types of Politeness Strategies used by the Lecturers and Students in English Class at Islamic College Jakarta.

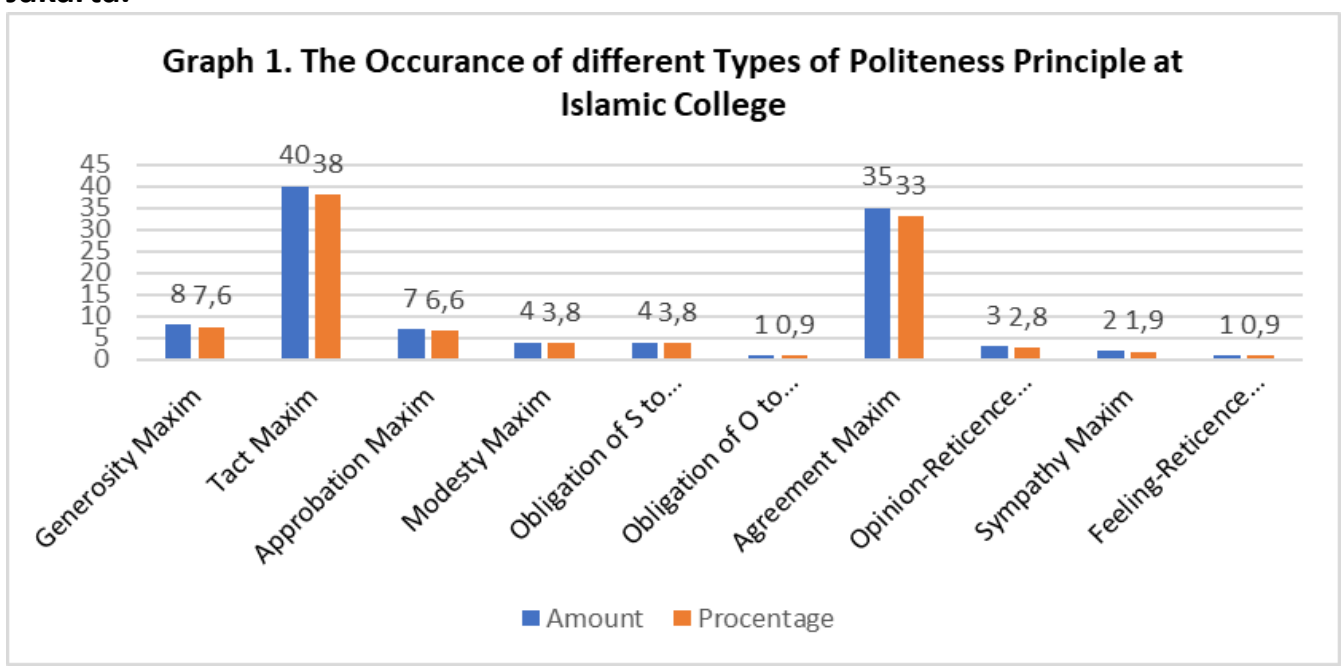

To be more details, there was data presented on the chart about which politeness principles used by each subject and how many times they used each politeness principles which was delivered according to the sequence of number of all data. By this chart, it is 
Lecturers' Politeness Strategies and Students' Compliance in English for Foreign Language (EFL) Class, Fitriyah, Nurmala Dewi, Octa Pratama Putra, Meiva Eka Sri Sulistyawati

found which type of politeness strategy was frequently used by the lecturers to the students. We can see the examples of the conversation between the lectures and the students.

\section{a) Politeness Principles in Tact Maxim Used by the Teachers to the Students}

Based on the data, the lecturers used tact maxim in their communication to the students because they want to reduce or minimize their benefit and maximize the benefit to others. Because of the researcher focused on the directive speech, the teachers used tact maxim when they are commanding, questioning, begging, and instructing, requesting, warning to the students. It can be seen in the data below.

The examples of tact maxim used by the teachers are follows:

Situation: In a speaking class (Class A), the lecturer (L1) discussed about transportation problem and asked the students $(\mathrm{S})$ about it.

S1: Congestion, you still can move, but gridlock you cannot move anymore, stuck.

L1: Stuck, we are stuck, okay! Another word for congestion? Traffic congestion is...??

S1: Traffic jam.

L1: Traffic jam, very good. Okay. See the composition here (she's pointing her left hand around the picture on the whiteboard). So they are not only cars, but also motorcycle. And then, what is this (pointing at the picture on the white board). Ya confused. Confused...? Stress. People are stress, people are confused, people are upset.

In this conversation above, the students explained the meaning of congestion. The lecturer thought that the answer is not complete or not enough. Then she asked the students about the other word of congestion. She used tact maxim when she was questioning to her students. The lecturer repeats the student's answer as a sign of her agreement and then asks another word of congestion, for giving an opportunity for the student to answer it. The teacher expressed it indirectly to show her politeness by saying Stuck, we are stuck, okay! Another word for congestion? Traffic congestion is...?? and Traffic jam, very good. Okay. See the composition here). By using this strategy, the lecturer tried to minimize her cost and maximize the students benefit.

According to Leech (2014), not all maxims have the same degree of importance. For example, he argues that the tact maxim is more influential than the generosity maxim. Using the concept of the tact maxim - the more tactful a directive, the more indirect and circumlocutionary it is. He also explains the importance of indirectness in polite speech acts.

Another example of tact maxim used by the lecturer can be found in this conversation below:

Situation: In a reading class (Class B) discuss about religion and the lecturer (L2) asked the students (S) about reading comprehension.

S1: I understand that the tone about the writer, it is descriptive.

L2: Descriptive ya. And then?

S1: and then the purpose, discuss about Christianity's gospel

L2: do you find some, any emotion, here?

S1: No. I don't

L2: No? So, it means just about descriptive reading, ok, then what about the purpose?

S1: Discuss about Christianity's Gospel 
In the conversation, it is found, that the lecturer used tact maxim in order to maximize benefit for others and minimize her own benefits. The utterances produced by the teacher are Descriptive ya. And then? And No? So, it means just about descriptive reading, ok, then what about the purpose?. They showed tact maxim used by the lecturer. Those are expressed indirectly that usually more polite than the speech acts expressed directly.

\section{b) Politeness Principles in Approbation Maxim Used by the Lecturer to the Students}

After analyzing the data, the researcher also found that the subjects also used approbation maxim as their politeness principle. This approbation maxim is to maximize respect for others and minimize the disrespect to others that expressed by expressive speech such as congratulated, thanked, praised, and express condolence. There were found four utterances produced by the teacher using this kind of maxim. The data were showed below:

Situation: In class A, the lecturer (L1) asked the students to make presentation for their homework.

S1: Just choose, Mom.

L1: Oh, just choose. Ok. Qotrun! (Lecturer stepped forward to Qotrun and sent her forward, then she sat behind with the students) Why?.....You ask me to choose, and I choose you, because I love you.

S1: May I bring my book?

L1: For glance is okay.

In this conversation, it is found that the lecturer used approbation maxim by saying oh just choose, Ok. The lecturer agreed the student's idea to choose who will have presentation in front of the class. Then the lecturer chose Qotrun. The utterance for glance is okay used when the lecturer agreed or gave permission for bringing a book when the students have presentation. By looking at the respond, the lecturer succeeded in using the politeness principles to get the students' attention and responses. Another example is following:

Situation: The lecturer (L1) asked the students about their transportation to campus.

L1: Junia?

S1: This is Junia, Mom.

S2: Always used transportation every day. To campus and back to dorm.

S3: Not every day.

L1: Not every day? Every day or not every day? Ok, one by one.

S3: Except Sunday.

L1: Ooh, except Sunday, ok. Yeah. I mean working days, every working days, almost every day? You are making me confused (laughing). Ok. And then, what did you take?? What kind of public transportation did you take? (still asking to Junia).

It is found that the lecturer used approbation maxim. In this conversation, the lecturer tried to maximize respect to Junia by using approbation maxim in her utterances. She produced an utterance, Ooh, except Sunday, ok. Yeah. Lecturer's utterance in this conversation was to praise Junia's answer and with the purpose of minimizing disrespect for her.

\section{c) Politeness Principles in Generosity Maxim Used by the Lecturers to the Students}

Based on the data, the researcher found that the subjects also used generosity maxim. The intent of this maxim is to make the advantages of the speaker as small as 
Lecturers' Politeness Strategies and Students' Compliance in English for Foreign Language (EFL) Class, Fitriyah, Nurmala Dewi, Octa Pratama Putra, Meiva Eka Sri Sulistyawati

possible. In this maxim, the participants are expected substitutions being respectful of others. Respect for others will happen if people can reduce profits for himself and maximize profits for others. The data are as the following:

Situation: The lecturer (Class C) asked the students about synonym words.

L3: What about the synonym?

S1: Beautiful and grace. Last and final

L3: Ok, that's good and then?

S1: Big and large

L3: ok, good, and then?

S1: Abundant

L3 : Ok, Abundant and?

After analyzing this utterance, it was showed that the lecturer used approbation maxim to praise the students' right answer by saying "that's good, ok good, ok". In this conversation, the lecturer tried to maximize respect to the students because they can answer the lecturer's question well.

\section{d) Politeness Principles in Modesty Maxim Used by the Students}

After analyzing the data, the modesty maxim used by the students is found in this conversation, but not by the lecturers. In this maxim, the speakers try to minimize the expression of praise of self and maximize of dispraise of self. This kind of politeness was one principle of politeness which was not used by the lecturers of Islamic College. They did not use modesty maxim as their politeness principles when they communicated with the students in directive and expressive speech acts at school.

In this research, modesty maxim is self-centered, the students were humble by reducing the praise to them. They dispraise themselves to other audience in assertive and expressive speech acts. The data are as the following:

Situation: The students (Class A) had a presentation about home remedies, and then they had answer question session.

S1: I think it would very painful. No, I mean is it painful?? Biting scars, open scars.

S2: No, no, no. I mean beside

S1: Oh beside. I see. You didn't mention it before.

S2: Sorry, sorry. I think you understand, that's good, that's good. Any question again? Come on just ask me.

L1: Ok. I think that's all ya? Thank you so much.

S1: Thank you so much guys.

\section{(e) Politeness Principles in Maxim of Obligation (of $\mathrm{S}$ to $\mathrm{O}$ Maxim) used by the Students}

Apologies for some offense by $\mathrm{S}$ to $\mathrm{H}$ are examples of polite speech acts giving high prominence to S's fault and obligation to O. Here are some typical brief examples, with the overtly apologetic forms. The data are as the following:

Situation: The students (Class A) had a presentation about home remedies, and then they had answer question session.

S1: I think it would very painful. No, I mean is it painful?? Biting scars, open scars.

S2: No, no, no. I mean beside.

S1: Oh beside. I see. You didn't mention it before.

S2: Sorry, sorry. I think you understand, that's good, that's good. Any question

L1: Ok. I think that's all ya? Thank you so much. 
S1: Thank you so much guys.

S1 apology is followed by a statement that justifies S2's opinion. The apology expressed by S1 is an expression of respect for the interlocutor. Thus, in the conversation there has been a maxim of the speaker's obligation to the opponent's speech.

\section{f. Maxim of Obligation of $\mathrm{O}$ to $\mathrm{S}$ Maxim Used by The Lecturer}

In this maxim the reverse or the response to the obligations carried out by speakers (Give a low value to $\mathrm{O}$ 'obligation to $\mathrm{S}$ ) applies. On the other hand, responses to apologies often minimize errors; for example utterance it's OK. don't worry. The speech can be found in the following conversation.

Situation: The lecturer (Class B) discussed about Religion and then he asked the questions to the students.

S1: I am sorry Sir, I don't finish it yet. Because last week I was sick.

L2: You don't finish it yet. It's Okay, Oh, you didn't study last week ya. The previous meeting. Miss...have you? (Pointing at someone). Okay come on, Mr. Adhika, come on what numbers did you criticize?

S2: 50 .

L2: 50. Ok.

In this conversation, it is found that the lecturer understands and accept the student didn't do the task, so the student felt that his face was not threatened. The lecturer carried out the maxim of obligation (of $\mathrm{O}$ to $\mathrm{S}$ maxim).

\section{g. Politeness Principle in Maxim of Agreement Used by The Student to the Lecturer}

Maxim agreement is expressed with expressive and assertive sentences. Maxim agreement outlines every speaker and others to say to maximize the compatibility between them and minimize incompatibility between them. The data are as the following:

Situation: The students (Class A) had a presentation about home remedies, and then they had answer question session.

S1: Water of cigarette maybe (then the whole class laugh together). When I was a child, I always bite by centipede on my feet, so my father always gives it (samsu) to me. And another home remedies like vinegar. You know vinegar? Sour and salty. When the centipede bites me, my father clean it with vinegar and give me bitter coffee for make me, the poisons is neutral. For making the poisons neutral, just like that.

L1: So, you have to drink the bitter coffee?

S1 : Yeah. Bitter coffee, I have to drink it and then give a salt in the injury, just like that. And it's for kids.

In this conversation above, when L1 gives a question or at the same time as an emphasis on the intention of the speaker So, you have to drink the bitter coffee? Then S1 justifies what L1 asks by repeating what is stated in question L1 Yeah. Bitter coffee, I have to drink it. In this conversation, there is a maxim of agreement between the students and the lecturer. Politeness Principle in maxim of agreement also used by the lecturer to the student, as the following data:

Situation: The lecturer (Class B) discussed about Religion and then he asked the questions to the students.

L2: About Christianity, and its belief?

S1: Yes.

L2: Then for course? 
Lecturers' Politeness Strategies and Students' Compliance in English for Foreign Language (EFL) Class, Fitriyah, Nurmala Dewi, Octa Pratama Putra, Meiva Eka Sri Sulistyawati

S1: Religion.

L2: Okay, its a part of religion. Ok, kategorinya berarti ini masuk ke..? masuk ke Religion. Ok, the others? Ms. Rany, have you? Ok Rany, come on

S2: I don't finish it Sir.

L2: You don't finish. Okay, Ms. Mela? Oh, you didn't study last week ya. The previous meeting. Miss...have you? (Pointing at someone). Okay come on, Mr. Adhika, come on what numbers did you criticize?

The conversations above L2 stating the agreement of the answers given S1 and S2.

\section{h. Politeness Principle in Opinion - Reticence Maxim Used by The Lecturer}

In this maxim, people frequently soften their own opinion (Give low value to S's opinions) by using propositional hedges, such as; I think, I guess, I don't suppose, It might be that. The data are showed below:

Situation: The lecturer (class A) discussed about transportation then asked students (M) about their daily use.

S1: Except Sunday

L1: Ooh, except Sunday, okay. Yeah. I mean working days, every working days, almost every day? You are making me confused (laughing). Ok. And then, what did you take?? What kind of public transportation did you take? (still asking to student)

The lecturer's statement implies that the lecturer wants to clarify her statement so that it is understood by the student, without being confused by it. The lecturer's statement saves student's face. Thus, the lecturer carries out the maxim of reticence.

\section{i. Politeness Principle in Maxim of Sympathy Used by Lecturer}

Maxim sympathy is expressed by assertive and expressive speech. The maxim of sympathy requires each participant to maximize sympathy and minimize the sense of antipathy to the opponent he said. The data is as followed:

Situation: The lecturer (class A) gives a greeting when she starts the lesson and hopes that the students are all good.

L1: Assalamu'alaikum warahmatullahi wabarakatuh, Good morning, boys and girls..

S1: Waalaikumsalam warahmatullahi wabarakatuh, Good morning Mam...

\section{L1: I hope all of you feeling fine to day}

S1: we hope so, Mam.

In this conversation, it is found that the utterance of lecturer about the condition of the students is to fulfill the principle of politeness of sympathy. Another data is as follows:

Situation: The lecturer (L1) discusses Home Remedies then asks students (S) to present their assignments. After the students present their assignments, the lecturer appreciates the assignments of students.

L1: Well.... we already heard about our experience in using home remedies, now, let's come back to our new topic ...it's our transportation problem. Now let me ask you some questions, like ...how do you go to school? Do you use public transportation or not?

S1: I'm not using public transportation every day, because when I go, I just enough walking.

\section{L1: Poor you}


In this conversation above, the lecturer states poor you. The lecturer's statement expressed her concern about the condition of his students.

\section{j. Politeness Principle in Feeling - Reticence Maxim}

In this maxim someone does not want to express their true feelings (Give a low value to someone's feelings). This maxim puts a low value on someone's feelings. Example of the utterances are in the following conversation.

Situation: The lecturer (class A) asked about the condition of some of her students who had just recovered from illness.

L1: Hi, Qotrun. Are you feeling better now? You were sick yesterday, right?

S1: I am getting much better, Mam

L1: Good, and Agus, are you OK now?

S1: Yes, Mam. I sometimes still feel dizzy, but I'm much better than yesterday.

These utterances reflect that the speaker (S1) was still in a state of illness; but, because he was asked by L1, he tried to explain her condition, thus eliminating the worry from the lecturer (L1). Thus, S1 carries out the maxims of hiding his feelings, in order to respect his lecturer's utterance.

Based on the data above, in a process of learning English, there are various ways to display politeness. In general, when communicating, each person will try to respect the wishes of other people's faces. The act of saving faces in communicating is often known as the politeness principles. This research is English politeness in class situations (speaking, grammar and reading). The interaction between lecturers and students creates a rather tense or rigid atmosphere, so they are less able to express themselves more freely so that variations in the use of language are less visible. It is necessary for the lecturer to apply politeness strategies in teaching and learning process, especially in EFL class which has different cultures. In this research, it is shown that the lecturer employed politeness strategy in their teaching process and how the stucents' compliance. Therefore, the use of politeness strategies needs to be applied by other lecturers in teaching. It is believed to stimulate students' learning motivation. The lecturers have to pay attention to their use of language in the classroom because it contributes to the learning process.

\section{Conclusion}

After analysing the data, the conclusions were stated that the lecturers of EFL class in Islamic College use ten types of politeness principles in directive and expressive speech act to communicate with the students at school. They were generosity maxim, tact maxim, approbation maxim, modesty maxim, agreement maxim, maxim of Obligation (of $S$ to O Maxim), maxim of obligation (of $S$ to $O$ ), Opinion - Reticence Maxim, sympathy maxim and feeling Reticence maxim. The dominant type of politeness principles used by the lecturer was tact maxim, because the lecturers were easier and felt more appropriate in using this type in directive speech acts as mostly focused on by the researcher. The students of EFL Class in Islamic College Jakarta don't comply with all the lecturer' utterances although they were already in polite way. They gave their compliances to some teachers' utterances. In the process of learning English, it is necessary to pay attention to the actual language function, namely as a communication tool. Thus, in the process of teaching English, the lecturer must not focus only on language rules grammatically, but also concerning to the use of practical language in everyday life. Especially the knowledge of politeness concepts in English which use may differ from our cultural background. 
Lecturers' Politeness Strategies and Students' Compliance in English for Foreign Language (EFL) Class, Fitriyah, Nurmala Dewi, Octa Pratama Putra, Meiva Eka Sri Sulistyawati

\section{References}

Bogdan, C. R., \& Bikien, K. S. (1992). Qualitative Research for Education. An Introduction to Theory and Methods. United States of America: Allyn and Bacon.

Brown, P., \& Levinson, S. (1987). Politeness: Some Universals in Language Usage. Cambridge University Press.

Celce-murcia, M. (2007). Celce-Murcia, M. (2007).pdf. Intercultural Language Use and Language Learning, 41-57.

Cialdini, R. B., \& Goldstein, N. J. (2004). Social Influence: Compliance and Conformity. Annual Review of Psychology, 55(1), 591-621. https://doi.org/10.1146/annurev.psych.55.090902.142015

Consolo, D. A. (2006). Classroom oral interaction in foreign language lessons and implications for teacher development. Linguagem \& Ensino, 9(2), 33-55.

Eelen, G. (2001). A Critique of Politeness Theories. Manchester, UK \& Northampton, MA: St. Jerome Publishing.

Eggins, S., \& D., S. (1997). Analysing Casual Conversation.

Ellis, R. (1997). Second Language Acquisition. USA: Oxford University Press.

Fitriyah, F., Emzir, E., \& Ridwan, S. (2019). Cultural Values of Politeness in Efl Classroom: a Study of Etnography of Communication. Language Literacy: Journal of Linguistics, Literature, and Language Teaching, 3(2), 207-216. https://doi.org/10.30743/Il.v3i2.1965

Goffman, E. (1967). On Face-Work an Analysis of Ritual Elements in Social Interaction. New York: Doubleday.

Jiang, X. (2010). A Case Study of T eacher' 's Politeness in EFL Class, 1(5), 651-655. https://doi.org/10.4304/jltr.1.5.651-655

Krippendorff, K. (2003). Content Analysis: An Introduction to Its Methodology Ch2 and 4. Content Analysis: An Introduction to Its Methodology. Retrieved from http://www.uk.sagepub.com/textbooks/Book234903

Lakoff, R. T., \& Ide, S. (2005). Broadening the horizon of linguistic politeness. Philadelphia USA: John Benjamins Publisihing company. https://doi.org/10.1080/00437956.2016.1180005

Leech, G. (2014). The Pragmatics of Politeness. The Pragmatics of Politeness, 1-368. https://doi.org/10.1093/acprof:oso/9780195341386.001.0001

Levinson, B. \&. (1987). Politeness (Brown and Levinson 1987 ). Reading.

Littlejohn, S. W., \& Foss, K. A. (2008). Theories of Human Communication. Harlow: Wadsworth Publishing Company.

Miles, M. B., \& A. Huberman, M. (1994). Qualitative Data Analysis, An expanded Sourcebook 2nd Edition.

Peng, L., Xie, F., \& Cai, L. (2014). A Case Study of College Teacher' s Politeness Strategy in EFL Classroom, 4(1), 110-115. https://doi.org/10.4304/tpls.4.1.110-115

Sabee, C. M., \& Wilson, S. R. (2005). Students' primary goals, attributions, and facework during conversations about disappointing grades. Communication Education, 54(3), 185-204. https://doi.org/10.1080/03634520500356154

Senowarsito. (2013). Politeness Strategies in teacher-student interaction in an EFL classroom context. TEFLIN Journal, 24, 82-96. https://doi.org/10.15639/TEFLINJOURNAL.V24I1/82-96

Song, S. (2012). Politeness and Culture in Second Language Acquisition. New York: Palgrave Macmillian. 
Watts, R. J. (2003). Politeness. Cambridge Uinversiy Press.

Zhang, Q. (2009). Teacher Request Politeness: Effect on students 'positive emotions and compliance intention. Fairfield University: Mexico. 